\title{
Water level fluctuations in Gallocanta Lake (Spain) using Sentinel-2 remote
}

\section{sensing.}

S. Morales; M. Ruiz; J. M. Soria*

* Corresponding author email: juan.soria@uv.es

Departament of Microbiology \& Ecology, Faculty of Biological Sciences, University of Valencia. 46100 Burjassot, Spain

\begin{abstract}
This study has been monitored for five years by Sentinel-2 satellite images, at different seasons of the year, of the fluctuations in the water level of the Gallocanta Lake (between the provinces of Teruel and Zaragoza, Aragón, Spain) considered a hypersaline and endorheic wetland, which has characteristics that make it unique in the geographical area in which it is located, as well as for the operation of the system. Rainfall in the area has a wide variation giving the maximums in the months of May and June and the minimums in January and February. There are considerable fluctuations in the water level from the almost total drying of the lagoon to the filling with a depth of approximately 3 meters.
\end{abstract}

Keywords: wetland, endorheic, saline, fluctuations, remote sensing 


\section{Introduction}

Wetlands have a distinguished value, both use and non-use, this is due to its multiple functions for the operation of the system as favour the existence of biodiversity, participate in the regulation of the hydrological cycle, among other functions. Their operation is strongly linked to groundwater, so they are vulnerable to actions such as the alteration or contamination of aquifers, agricultural increase, urban expansion, etc. (Díaz de Arcaya et al., 2005).

Protected areas such as wetlands have an international designation in the Ramsar Convention, which promotes the formation of an international network of wetlands and thus the conservation of those wetlands included in the Ramsar List. A total of 75 Spanish wetlands are inscribed on this list, covering an area of 304,541 ha, including the Gallocanta Lagoon since 1994 (Arnaiz, 2013; Ramsar, 2020).

Wetlands are of relevant interest to the scientific community due to their fragility, since they contain migratory and locally endemic species that are threatened by the vulnerability of these to drought events, urban settlements, ecosystem fragmentation, and water imbalance, among other aspects. In addition to the great benefits it provides for society and biodiversity, as a $40 \%$ carbon sink, protection from severe storms, control of strong winds, stabilization of coasts, etc. (Moya et al., 2005). For its conservation, a useful tool is remote sensing since in a simple and optimal way it is possible to monitor, study the uses and coverage of the soil, as well as make the necessary decisions for the management of the territory (Jiménez et al., 2015).

The Gallocanta Lake is a specific type of wetland zone that is currently rare in its biographical area, as it is an endorheic brackish lake in the Mediterranean area of the Western Palaearctic (Casterad and Castañeda, 2009). Furthermore, it is considered unusual because the water level shows different seasonality and greater period of fluctuation compared to other saline lakes in Spain (Comín and Alonso, 1988). All of this is of relevant interest in order to place more emphasis on this lake, which is considered to be the best preserved in Western Europe, and where remote sensing is a tool that can be useful for its management (Jiménez et al., 2015).

This work aims to update the available information on Gallocanta Lake related to water coverage fluctuations, using Sentinel-2 images and different methodologies. In this way, through the new Copernicus satellite, we intend to renew the existing information on the study area, which has been paralyzed for years, by means of satellite images that provide us with knowledge of the area without losing quality in the research.

\section{Material and methods}

The Gallocanta Lake is an endorheic and saline wetland located between the provinces of Zaragoza and Teruel (Díaz de Arcaya et al., 2005), more specifically between the regions of Jiloca and Campo de Daroca (40 $58^{\prime}$ $\mathrm{N} / 01^{\circ} 30^{\prime} \mathrm{W}$ ), as shown in Figure 1, including the municipalities of Gallocanta, Santed, Berrueco and Las Cuerlas (Zaragoza) and in Bello and Tornos (Teruel). Its extension consists of 1,924 ha of Natural Reserve and 4,553 ha of Peripheral Protection Zone. It has an extension of $14.4 \mathrm{~km}^{2}$, with dimensions of $2.8 \mathrm{~km}$ wide by $7.7 \mathrm{~km}$ long. It has a maximum capacity of $5 \mathrm{hm}^{3}$ and an average depth of $45-50 \mathrm{~cm}$, although it can reach 
3 meters in the high-water season. (Comín, et al., 1991; Velasco, 2006; Arnaiz, 2013; Gracia and Castañeda, 2018). Its basin is between a minimum and maximum altitude of 995 meters and 1085 meters, respectively (Government of Aragon, 2020). Due to its biological, geological and hydrological uniqueness, it is considered one of the most important ecosystems in the Iberian Peninsula and Western Europe. Therefore, this enclave has certain protection figures such as Ramsar site, LIC (Place of Community Importance), ZEPA (Special Protection Area for Birds), among others (Casterad and Castañeda, 2009; Arnaiz, 2013).

From the geological point of view, the Gallocanta Lake is located at the bottom of an old polje, forming part of an endorheic basin with a multifunctional origin, between karstic and structural. It was formed at the end of the Tertiary Era and continued throughout the Quaternary Era (Velasco, 2006; Arnaiz, 2013). Morphologically, the Gallocanta Lake is structured in three areas (from north to south): the Lagunazo and the Lagunazo Grande, joined by the strait, and the Lagunazos de Tornos, to the south. Being in the Lagunazo Grande where the lake has the maximum depth, the Lagunazos de Tornos constitute a flooded marsh area, in those occasions when the Lagunazo Grande suffers an overflow (Casterad and Castañeda, 2009).

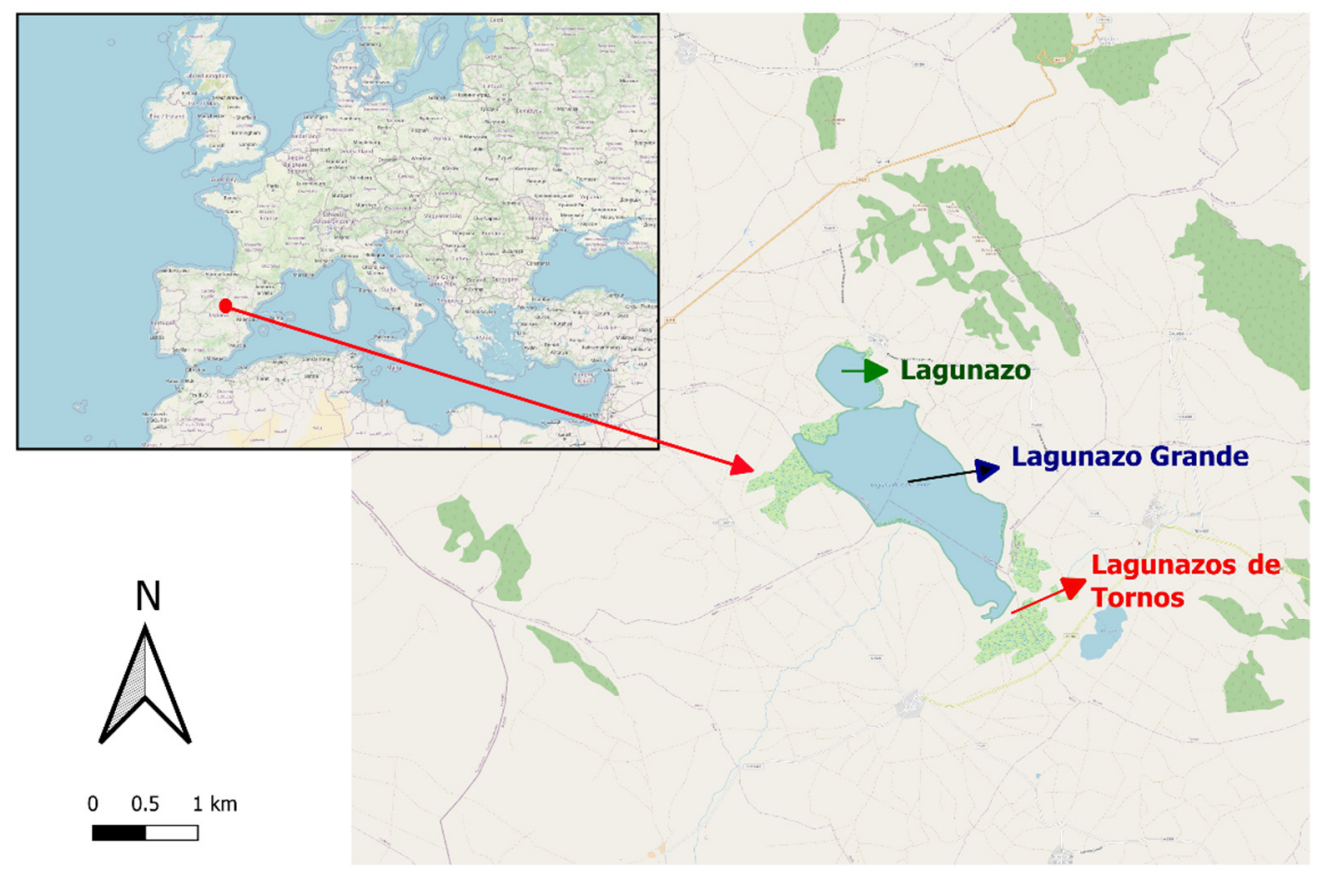

Figure 1. Location map of the Gallocanta Lake indicating the three flooded areas (Source: Own elaboration from OpenStreetMap).

The climate present in the lake area and its surroundings is semi-arid semi-continental Mediterranean, common in the steppes of intermediate latitudes. Maximum rainfall occurs between the months of May and June, while minimum rainfall occurs in the months of July, August, January and February. As for the precipitations, they are around $500 \mathrm{~mm}$, with a wide pluviometric variation, which produces fluctuations in the water level between total desiccation and almost 3 meters deep (Gracia and Castañeda, 2018). While the average annual temperature is $10.7{ }^{\circ} \mathrm{C}$, the maximum monthly average recorded in July is $21.1{ }^{\circ} \mathrm{C}$ and the 
minimum in January is $2.9^{\circ} \mathrm{C}$. It also has a great amplitude between the absolute maximum and minimum temperatures, recorded at $39{ }^{\circ} \mathrm{C}$ and $-21{ }^{\circ} \mathrm{C}$, respectively. Winds are frequent from the northwest (NW), reaching speeds above $80 \mathrm{~km} / \mathrm{h}$ (Pérez and García, 2000; Velasco, 2006).

The study consists of a multi-temporal analysis (2015-2019) in order to have more information about the filling and emptying period of Gallocanta Lake. The scenes corresponding to the UTM T30XL grid of the Sentinel-2 platform of the ESA (European Space Agency) have been downloaded from the Copernicus Open Access Hub portal at https://scihub.copernicus.eu/, and from NASA at https://earthexplorer.usgs.gov due to the inability to download from ESA (because some of them are offline) at the time of the work. We have preferred to download the images in MSIL2A format already corrected geometrically and atmospherically; when they were not available, they have been downloaded in MSIL1C format which is not atmospherically corrected. Subsequently, they have been processed by SNAP (Sentinel Application Platform) image processing software using B1-B8A bands, performing a resampling process at 10x10 m pixels and the atmospheric correction in L1C images by the C2RCC method implemented in SNAP. Then, the vegetation and water indices, NDVI and MNDWI, respectively, have been calculated, as well as a thematic classification of the soil not supervised by the K-means Cluster Analysis method.

Based on the results of the indices and classification, the maximum flooded area of the lagoon has been calculated for each year of study, considering the choice of the most appropriate date. The procedures used for this were an unsupervised K-means classification and the MNDWI water index with the same image size in each process and year. In the first case, we have obtained the size (in pixels) of the image with the width and length, and then converted to square meters by multiplying by 100 so that having previously made a resampling 10x10 each pixel is $100 \mathrm{~m}^{2}$. Then, an unsupervised K-means classification is made, with bands 2$3-4-8$, so that the percentage of the class belonging to the flooded area is known. In the second case, the MNDWI water index has been carried out followed by a histogram in which the range of coverage by water is selected, and with it, the number of pixels and square meters present in it. In this way, the maximum water surface areas of the wetland are compiled for each year of study, taking into account that the results offered are indicative since field work is of primary importance to validate the measurements obtained.

\section{Results}

The images downloaded from ESA's Sentinel-2 platform through the Copernicus Open Access Hub and NASA's website were 47, whose dates are listed in Table 1, and from which 19 images have been selected so as to have an image of the lagoon for each season of the year, the ones chosen being marked in bold in that table.

Subsequently, those satellite images have been selected in which the maximum and minimum water levels can be seen, as well as the intermediate phases it undergoes in the different seasons of the year, taking as a reference the average monthly rainfall in the Bello pluviometric station (see Table 2). 
Table 1. Dates of downloaded images and, in black, those selected for season study.

\begin{tabular}{|l|l|l|l|l|}
\hline $\mathbf{2 9 / 0 7 / 2 0 1 5}$ & $12 / 01 / 2016$ & $25 / 02 / 2017$ & $31 / 01 / 2018$ & $26 / 01 / 2019$ \\
\hline $25 / 08 / 2015$ & $09 / 02 / 2016$ & $\mathbf{2 0 / 0 3 / 2 0 1 7}$ & $\mathbf{2 6 / 0 4 / 2 0 1 8}$ & $25 / 02 / 2019$ \\
\hline $24 / 09 / 2015$ & $\mathbf{1 4 / 0 4 / 2 0 1 6}$ & $16 / 04 / 2017$ & $09 / 05 / 2018$ & $27 / 03 / 2019$ \\
\hline $\mathbf{1 6 / 1 1 / 2 0 1 5}$ & $01 / 05 / 2016$ & $26 / 05 / 2017$ & $25 / 06 / 2018$ & $29 / 04 / 2019$ \\
\hline \multirow{4}{*}{} & $\mathbf{2 0 / 0 6 / 2 0 1 6}$ & $\mathbf{1 8 / 0 6 / 2 0 1 7}$ & $28 / 07 / 2018$ & $\mathbf{3 1 / 0 5 / 2 0 1 9}$ \\
\cline { 2 - 6 } & $30 / 07 / 2016$ & $28 / 07 / 2017$ & $\mathbf{2 7 / 0 8 / 2 0 1 8}$ & $30 / 06 / 2019$ \\
\cline { 2 - 6 } & $\mathbf{1 9 / 0 8 / 2 0 1 6}$ & $\mathbf{1 4 / 0 8 / 2 0 1 7}$ & $23 / 09 / 2018$ & $28 / 07 / 2019$ \\
\cline { 2 - 6 } & $23 / 09 / 2016$ & $23 / 09 / 2017$ & $\mathbf{0 3 / 1 0 / 2 0 1 8}$ & $\mathbf{2 4 / 0 8 / 2 0 1 9}$ \\
\cline { 2 - 6 } & $\mathbf{2 9 / 1 0 / 2 0 1 6}$ & $\mathbf{2 6 / 1 0 / 2 0 1 7}$ & $12 / 11 / 2018$ & $26 / 09 / 2019$ \\
\cline { 2 - 6 } & $\mathbf{1 7 / 1 1 / 2 0 1 6}$ & $22 / 11 / 2017$ & $\mathbf{3 0 / 1 2 / 2 0 1 8}$ & $\mathbf{2 6 / 1 0 / 2 0 1 9}$ \\
\cline { 2 - 6 } & $30 / 12 / 2016$ & $\mathbf{2 5 / 1 2 / 2 0 1 7}$ & & $\mathbf{3 0 / 1 2 / 2 0 1 9}$ \\
\cline { 2 - 5 } & & & &
\end{tabular}

Table 2. Accumulated monthly rainfall (in mm) in the locality of Bello (Teruel) during the period 2015-2019. Bluish shading for those months with high rainfall and pink colored for those months with low rainfall (Own elaboration from the data present in the Aragonese Institute of Statistics)

\begin{tabular}{|c|c|c|c|c|c|c|c|c|c|c|c|c|}
\cline { 2 - 15 } \multicolumn{1}{c|}{} & \multicolumn{10}{c|}{ Monthly rainfall at BELLO (TERUEL) between 2015-2019 } \\
\cline { 2 - 15 } \multicolumn{1}{c|}{} & Jan. & Feb. & Mar. & Apr. & May & Jun. & Jul. & Aug. & Sep. & Oct. & Nov. & Dec. \\
\hline $\mathbf{2 0 1 5}$ & 15,6 & 15,0 & 41,8 & 20,8 & 30,0 & 83,0 & 30,0 & 14,0 & 6,2 & 14,8 & 38,6 & 0,6 \\
\hline $\mathbf{2 0 1 6}$ & 34,2 & 34,8 & 31,1 & 32,4 & 10,4 & 9,0 & 1,7 & 10,4 & 13,2 & 31,0 & 73,4 & 4,8 \\
\hline $\mathbf{2 0 1 7}$ & 12,8 & 19,0 & 26,6 & 17,5 & 26,0 & 38,2 & 5,4 & 34,6 & 8,4 & 1,2 & 4,0 & 10,2 \\
\hline $\mathbf{2 0 1 8}$ & 20,4 & 27,5 & 40,8 & 80,0 & 109,5 & 25,5 & 13,0 & 50,3 & 39,5 & 129,5 & 29,6 & 13,8 \\
\hline $\mathbf{2 0 1 9}$ & 15,0 & 2,0 & 16,8 & 102,0 & 24,5 & 4,4 & 35,0 & 31,0 & 20,8 & 36,5 & 54,8 & 28,5 \\
\hline
\end{tabular}

As shown in table 3 and figure 2, which dates back to May 31,2019, the Gallocanta Lake has a large water capacity, being one of the largest water areas in the study, due to the rainfall in the area in that month (24.5 $\mathrm{mm})$ and, mainly, the previous month $(102.0 \mathrm{~mm})$, resulting in a dark green color of the wetland and surrounding agricultural fields.

Table 3. Maximum surfaces of the Gallocanta Lake during the years of study through unsupervised K-means classification and MNDWI water index.

\begin{tabular}{|c|c|c|}
\hline Date & K-means & MNDWI \\
\hline $19 / 07 / 2015$ & $9607800 \mathrm{~m}^{2}\left(9,61 \mathrm{~km}^{2}\right)$ & $9394400 \mathrm{~m}^{2}\left(9,39 \mathrm{~km}^{2}\right)$ \\
\hline $17 / 11 / 2016$ & $9199600 \mathrm{~m}^{2}\left(9,20 \mathrm{~km}^{2}\right)$ & $8803000 \mathrm{~m}^{2}\left(8,80 \mathrm{~km}^{2}\right)$ \\
\hline $14 / 08 / 2017$ & $8845300 \mathrm{~m}^{2}\left(8,85 \mathrm{~km}^{2}\right)$ & $8231200 \mathrm{~m}^{2}\left(8,23 \mathrm{~km}^{2}\right)$ \\
\hline $25 / 06 / 2018$ & $8778600 \mathrm{~m}^{2}\left(8,78 \mathrm{~km}^{2}\right)$ & $9335100 \mathrm{~m}^{2}\left(9,34 \mathrm{~km}^{2}\right)$ \\
\hline $29 / 04 / 2019$ & $9313500 \mathrm{~m}^{2}\left(9,31 \mathrm{~km}^{2}\right)$ & $10185100 \mathrm{~m}^{2}\left(10,19 \mathrm{~km}^{2}\right)$ \\
\hline
\end{tabular}



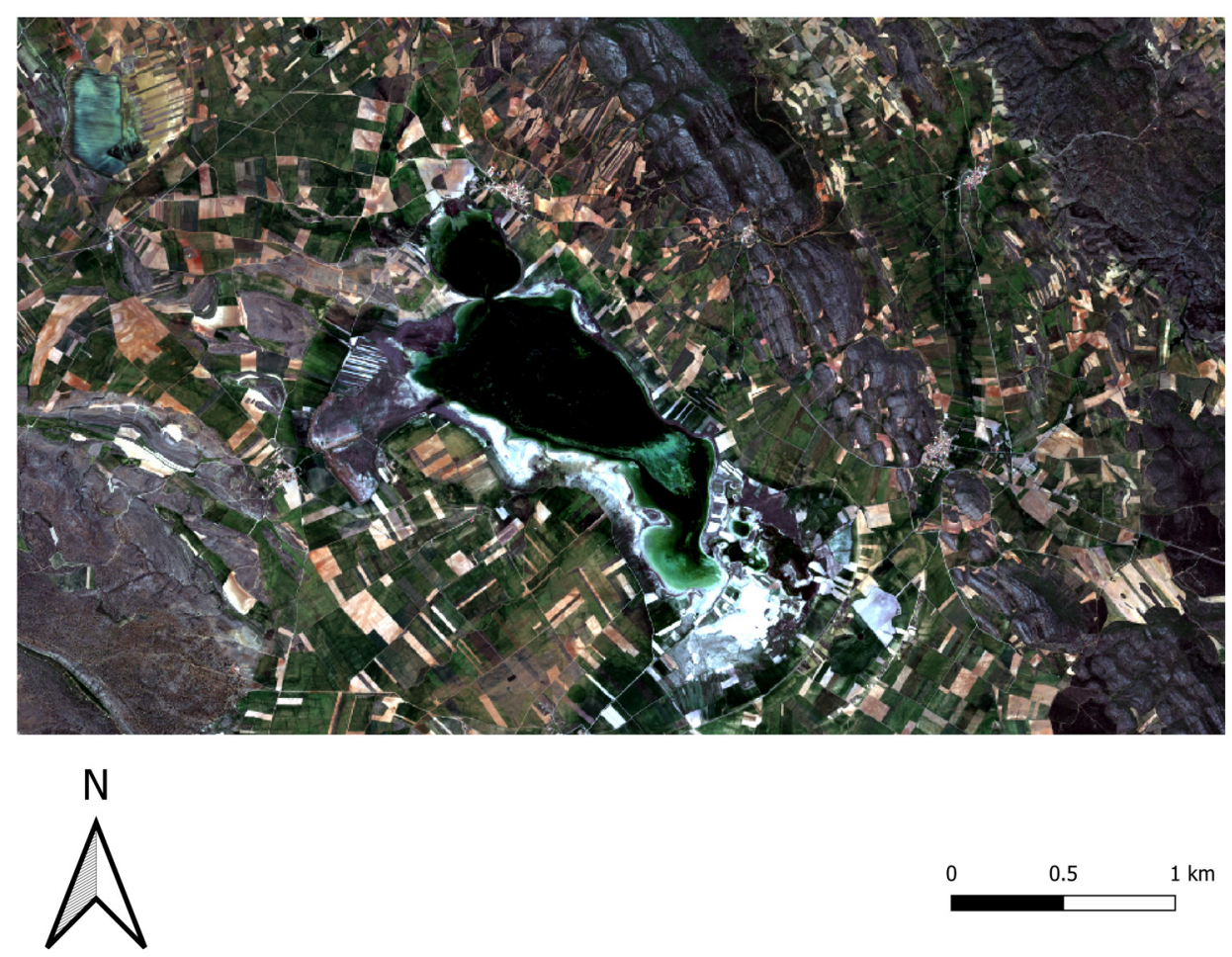

Figure 2. Maximum observed flooding in Gallocanta Lake. Sentinel-2 image from May 31, 2019. RGB elaboration from 4-3-2 bands.

In contrast, Figure 3, which dates from 22 November 2017, the Gallocanta Lake is observed to be dry due to an extremely dry year coupled with a sequence of months without significant precipitation (September 8.4 $\mathrm{mm}$, October $1.2 \mathrm{~mm}$, November $4.0 \mathrm{~mm}$ ). In the image, the lagoon is completely whitish due to the saline efflorescence caused by being at the minimum annual water level and the karstic character of the area.
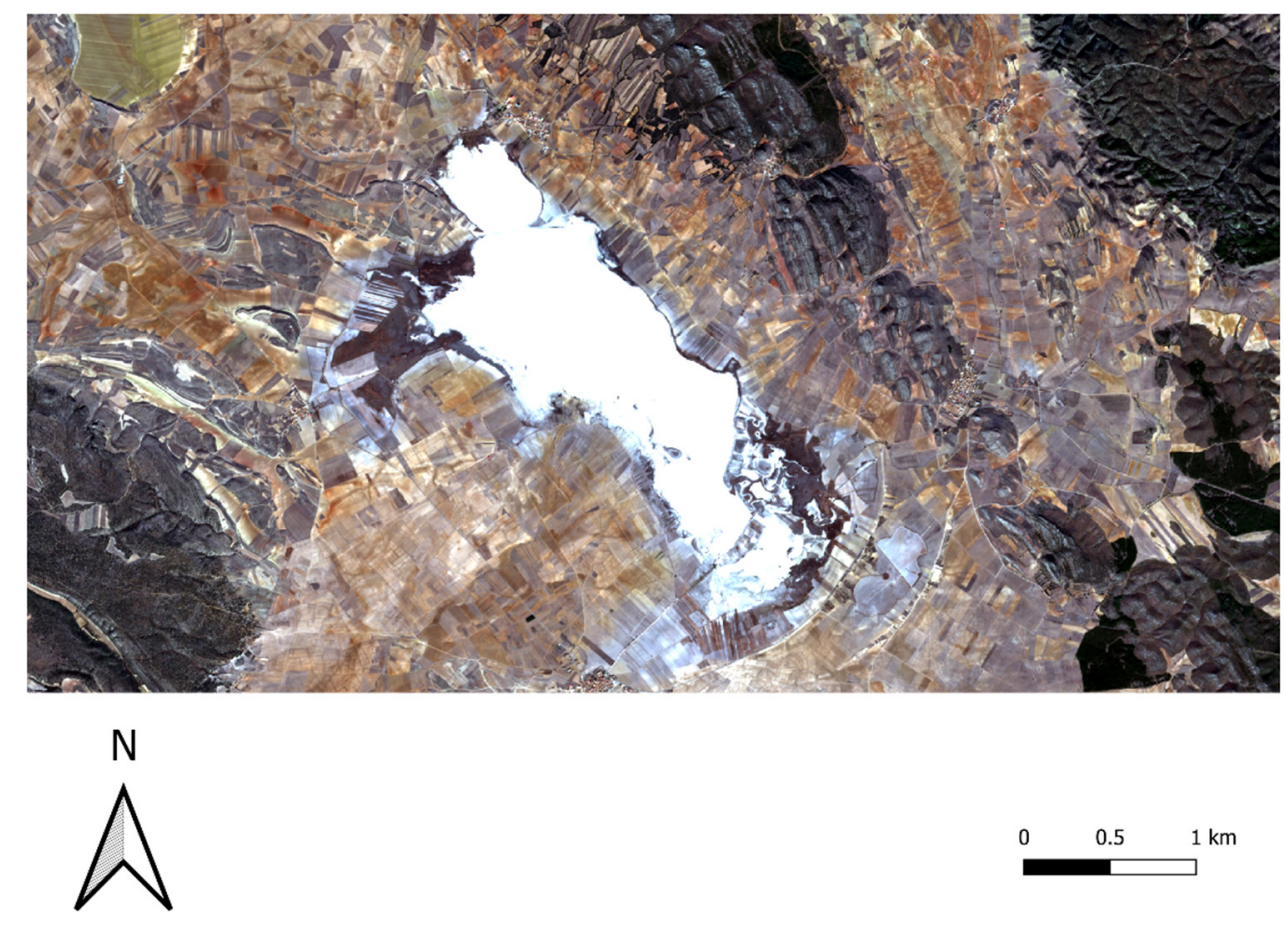

Figure 3. Gallocanta Lake in dry season. Imagen Sentinel-2 of November 22, 2017, RGB 432.

In an intermediate situation, Figure 4, which dates from July 29, 2015, is available. In this case, the lake is found in various colors, with the external zone being white, bare soil due to saline efflorescence, and the blue- 
green zone showing a sheet of water with different depths depending on the zone and color, with the maximum being reached in the central zone in green color.
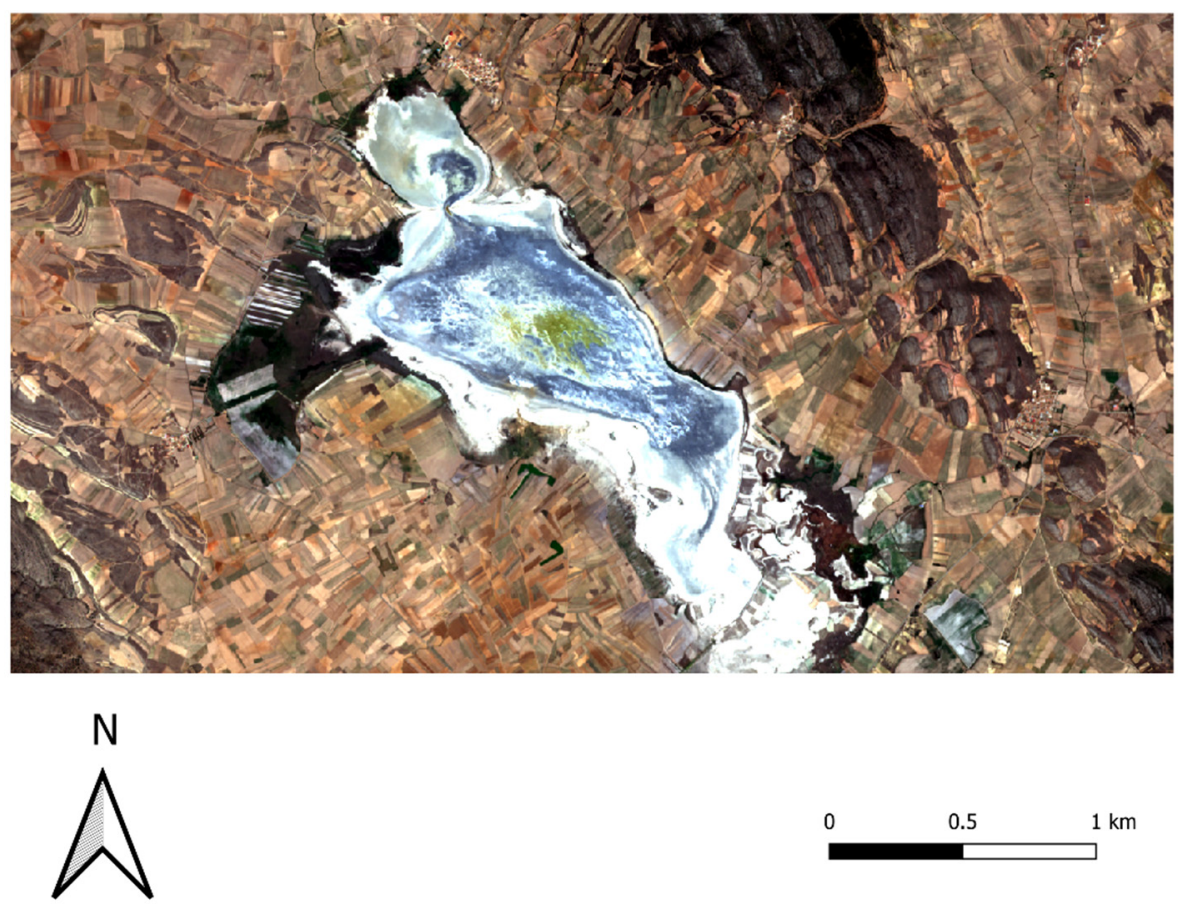

Figure 4. Aspect of Gallocanta Lake in intermediate flooding season. Sentinel-2 image from July 29, 2015, RGB 432.

In order to know the functional areas of the lagoon, an unsupervised classification has been made with seven classes, in different seasons of the year, in order to give them the values of flooded areas, temporarily covered with water, wet or dry, and to evidence their direct or indirect relationship with the fluctuations, in addition to the calculation of the maximum surface of the lagoon together with the MNDWI water index. Comparing the thematic classes obtained with the values provided in portals such as Iberpix or SIG Aragon, they were provided with a land use corresponding to their color. Some examples of this classification and the water index are shown in Figure 5 and 6, respectively.

Each year has a different water cycle due to the amount of rain collected in the area, presented by months in table 2, suffering various annual and interannual fluctuations visible in satellite images. In 2015 there are not enough images to know exactly how long it has been flooded, although by observing the rainfall parameter in the area it can be assumed that between March and July the lagoon suffers a rise in water level due to rainfall of around $20.8-83.0 \mathrm{~mm}$, while the rest of the year (August-February) remains dry or with a minimum sheet of water as it does not manage to exceed $15.6 \mathrm{~mm}$ per month, except for November which records $38.6 \mathrm{~mm}$ which gives it a break after several months practically dry. 


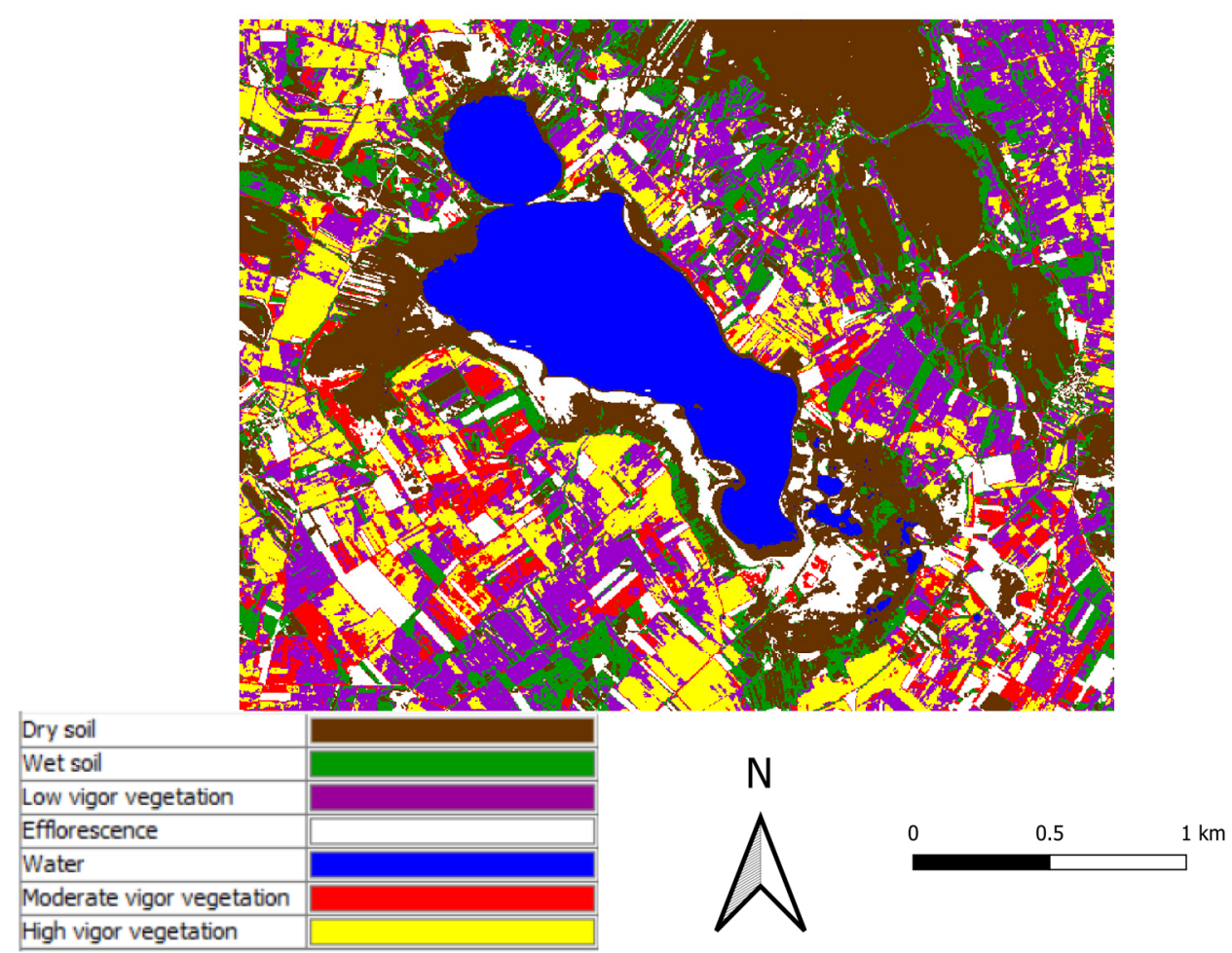

Figure 5. Unsupervised K-means classification of Gallocanta Lake, image of April 29, 2019. Separation into seven classes.

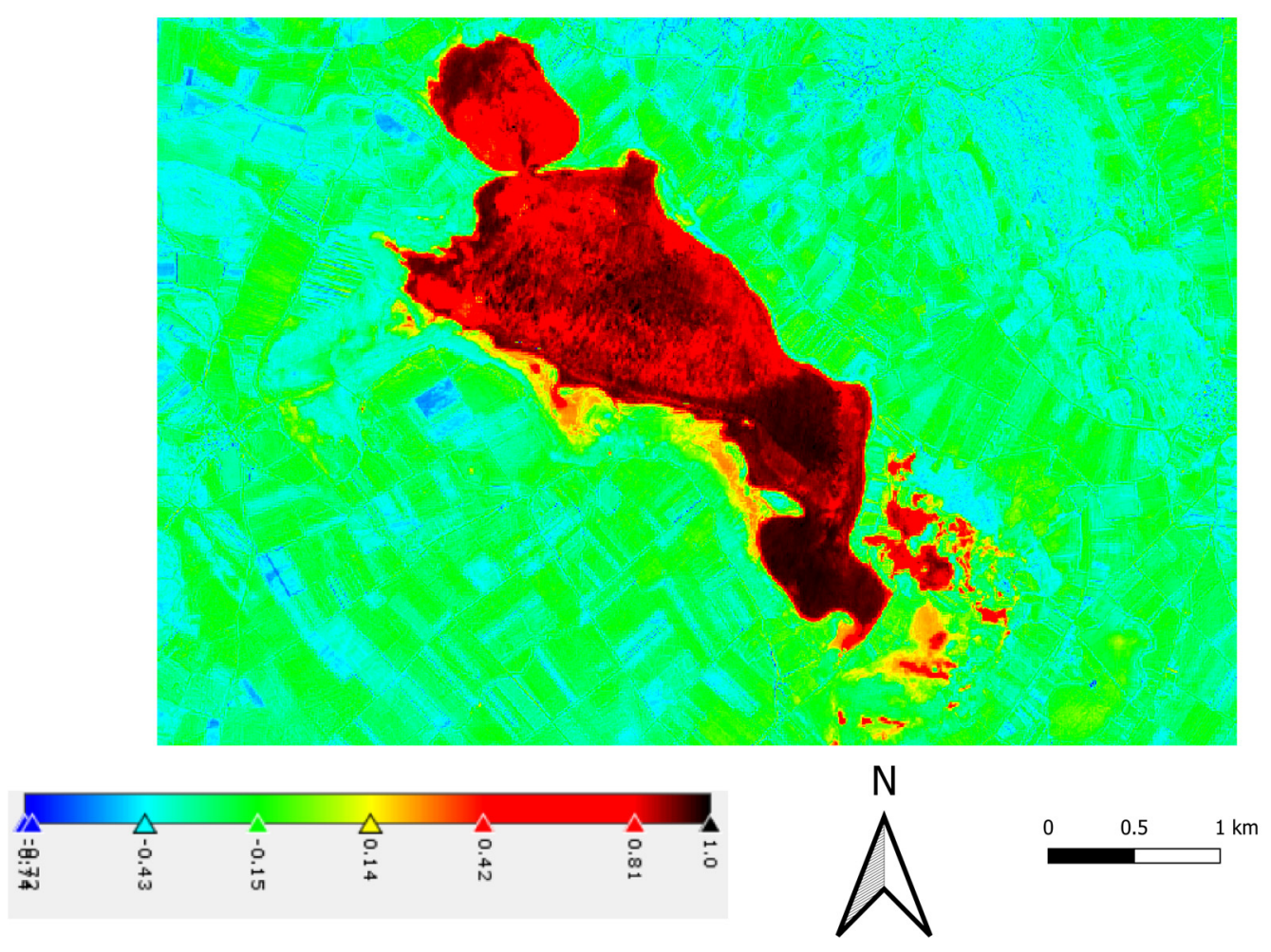

Figure 6. Colored MNDWI water index of Gallocanta Lake, image of April 29, 2019.

During the year 2016, it remains green with a large amount of water during the first four months of the year (January-April) with rainfall of around 31.0 - $35.0 \mathrm{~mm}$, the following four months (May-August) were dry with rainfall between 1.7 and $10.4 \mathrm{~mm}$ dropping to a sheet of blue water, and finally, the last four months rain 
returns, mainly in the month of November reaching the peak of the year with $73.4 \mathrm{~mm}$, which was not enough to prevent the efflorescence of the lagoon. The year 2017 is considered the driest of the years studied, with the months of June and August being the highest average monthly rainfall with a value of 38.2 and $34.6 \mathrm{~mm}$ respectively, which gives a sheet of water to the lagoon after an almost dry start to the year. The total dryness arrives in October until December given the scarcity of precipitation producing a complete efflorescence in the lagoon. With the entrance of 2018 the precipitations return giving it a green aspect and reaching wide surface throughout the whole year being the images of June and November the most outstanding since they surpass the month previous to each one they received a contribution superior to $100 \mathrm{~mm}$, suffering a gradual descent of the level every month between one and another (July - October). Finally, in the year 2019, the first months the lagoon remains full and of a spectacular green color, as well as La Zaida especially after the rains of April where the lagoon reaches its maximum capacity in the study, until June where with the entrance of the summer station it begins to dry up getting to touch the drying up in October.

\section{Discussion}

With this procedure, projects and ideas of different nature can be developed with less time and effort, as well as with a result of relevant importance. In this case, it has been possible to carry out a study for the evaluation of the annual fluctuations of the water level in the Gallocanta Lake without the need for field sampling, although this does not exempt it from being necessary for a superior knowledge of the terrain and a more specific and professional result in the study. Apart from this type of function, remote sensing offers many other services from a naturalistic point of view, mainly focused on the management and conservation of a natural area.

There are several studies in which different aspects of the lagoon have been studied by remote sensing, as well as other places and atmospheric phenomena. We must highlight the studies by remote sensing in the area of the Gallocanta Lake over time. Pérez and García (2000) carried out a microclimatic study of the lagoon in which through TM satellite images of Landsat 5, NOAA AVHRR and field data, they reached the conclusions that there is an outstanding thermal damping effect and the thermal behavior of the study area was recorded. Later on, they will cooperate again in Pérez and García (2015) where the fluctuations of the lagoon are monitored from field data and the Landsat satellite, observing the intra- and interannual oscillations, as well as their relation with the fluctuations of dry and wet years and the uses of the waters of the basin. Two articles of interest were made by Castañeda et al. (2015) consisting of a multi-temporal study of the lagoon through the automation of the treatment of the satellite images available in Landsat 5, as well as the monitoring of the crops present in the perilagunar area by means of the NDVI index. And by Jiménez et al. (2015) in which also through TM Landsat 5 images, relevant humidity maps were generated, useful for decision making about the management of the lagoon since it provides the necessary information to understand its functioning through humidity patterns, edaphic features or the landscape. Finally, Lemenkova (2016) confirms that, after 
calculating the direction and length of current flow in the lagoon basin, the lagoon has sensitive hydrological configurations that explain why it is more prone to environmental changes.

Following the dynamics of the calculation of the maximum water surface of the lagoon, the first research dates back to 1926 when Francisco Hernández-Pacheco and Pedro Aranegui visited the lagoon, and as indicated in Galván (2011) they documented an approximate surface area of $20 \mathrm{~km}^{2}$. Later, multiple studies show with satellite images what is considered the largest area recorded, dated $14.4 \mathrm{~km}^{2}$ in the 1970 s considered a particularly wet decade (San Roman et al., 2007; García et al., 2009; Arnaiz, 2013). In a similar study conducted by Castañeda and Herrero (2009) between 1987 and 1994, the maximum extension of the lake was $11.64 \mathrm{~km}^{2}$ in June 1989. Comparing the maximum result of this study according to the image of April 29, 2019 , of $11.58 \mathrm{~km}^{2}$ is similar to the case cited. Observing the processes carried out and their corresponding results, the MNDWI water index is closer to reality since it is easier to select the range with presence in water as opposed to the K-means classification where there is a classification whose result is dependent on the number of classes and the water surface; therefore, also on the total surface obtained from the lagoon.

\section{Conclussions}

Sentinel-2's satellite image processing through SNAP software and its use has been a great help on the job, making it possible to do efficient and effective desktop work without the need to travel to the study area temporarily to monitor the wetland. In addition, its similarity to other remote sensing programs and geographic information systems makes it comfortable and intuitive to use, with virtually no problems. The maximum area of the lagoon is consistent with the results of other more recent work prior to this one. Future lines of research should be related to the collection of field data during the different seasonal periods and, with it, the improvement of the unsupervised classification of land uses.

\section{References}

Arnaiz, S.L. ARA075: Laguna de Gallocanta. Instituto Geológico y Minero de España. Último acceso: 21 de Julio, 2020, de http://info.igme.es/ielig/LIGInfo.aspx?codigo=ARA075

Castañeda, C., Herrero, J. 2009. Teledetección de cambios en la Laguna de Gallocanta. En Casterad, M.A., Castañeda, C. La Laguna de Gallocanta Medio natural, conservación y teledetección (pp. 103-126). Madrid: Memorias de la Real Sociedad Española de Historia Natural.

Castañeda, C., Jimenéz, A., Latorre, B., Luna, E. 2015. Tratamiento automático de imágenes Landsat en entorno SIG para gestión de espacios protegidos: Laguna de Gallocanta, España. En: XVI Congreso de la Asociación Española de Teledetección. Sevilla, España, 21-23 Octubre 2015. pp 36-39. 
Casterad, M.A., Castañeda, C. 2009. La Laguna de Gallocanta Medio natural, conservación y teledetección. Madrid: Memorias de la Real Sociedad Española de Historia Natural.

Comín, F.A., Alonso, M. 1988. Spanish salt lakes: Their chemistry and biota. Hydrobiologia, 158, 237-245. https://doi.org/10.1007/BF00026281

Comín, F.A., Julià, R., Comín, P. 1991. Fluctuations, the key aspect for the ecological interpretation of saline lake ecosystems. Oecologia aquatica, 10, 127-135.

Departamento de Agricultura, Ganadería y Medio Ambiente. Reserva Natural Dirigida Laguna de Gallocanta. Gobierno de Aragón. Último acceso: 20 de Julio, 2020, de https://www.aragon.es/-/reserva-natural-de-lalaguna-de-gallocanta\#anchor1

Díaz de Arcaya, N., Castañeda, C., Herrero, J., Losada, J.A. 2005. Cartografía de coberturas asociadas a las fluctuaciones de la Laguna de Gallocanta. Revista de la Asociación Española de Teledetección, 24, 61-65.

Galván, R. 2011. Evolución histórica de la laguna de Gallocanta. Un análisis documental. Xiloca, 39, 69-98.

García, M.A., San Román, J., Blasco, O., Coloma, P. 2009. Hidrogeología de la Laguna de Gallocanta e implicaciones ambientales. En La Laguna de Gallocanta Medio natural, conservación y teledetección (pp. 77-101). Madrid: Memorias de la Real Sociedad Española de Historia Natural.

Gracia, F.J., Castañeda, C. 2018. Interpretación y cartografía de paleolíneas de costa lacustres mediante fotografías aéreas de alta resolución y datos LiDAR en la Laguna de Gallocanta (NE España). Cuaternario y Geomorfología, 32(1-2), 31-51. https://doi.org/10.17735/cyg.v32i1-2.62066

Instituto Aragonés de Estadística. Clima/ Datos climatológicos. IAEST. Último acceso: 27 de Julio, 2020, de https://servicios3.aragon.es/iaeaxi/tabla.do?path=/14/05/02/\&file=14050201.px\&type $=$ pcaxis $\& \mathrm{~L}=0$

Jiménez, A., Luna, E., Castañeda, C. 2015. Integración de datos territoriales de la Reserva Natural de la Laguna de Gallocanta como base para su gestión. Análisis espacial y representación geográfica: innovación y aplicación, 1689-1698.

Lemenkova, P. 2016. Using GIS for Monitoring Lacustrine Ecosystem: a Case Study of Laguna de Gallocanta, Spain. En: Proceedings of the Russian National Scientific Conference 'Problems of the Environmental Landscape Planning', Novocherkassk, Russia, 25-27 Abril. pp 237-240.

Moya, B.V., Hernández, A.E., Elizalde, H. 2005. Los humedales ante el cambio climático. Investigaciones Geográficas, 37(37), 127-132. https://doi.org/10.14198/INGEO2005.37.07 
Pérez, M.E., García, M.P. 2000. Estudio Microclimático de la Laguna de Gallocanta. Tecnologías Geográficas para el Desarrollo Sostenible, 102-114.

Pérez, M.E., García, M.P. 2015. Fluctuaciones hídricas de la laguna de Gallocanta analizadas a partir de teledetección. Ería, 96, 97-106.

Ramsar. España. Ramsar. Último acceso: 21 de Julio, 2020, de https://www.ramsar.org/es/humedal/espana

San Román, J., García, M.A., Blasco, O., Coloma, P. 2007. Hidrogeología de la laguna de Gallocanta. Xiloca, 35, 65-86.

Velasco, R.A. Ficha Informativa de los Humedales de Ramsar. Ministerio para la Transición Ecológica y el Reto Demográfico. Último acceso: 21 de Julio, 2020, de https://www.miteco.gob.es/images/es/29 fir_gallocanta_0 tcm30-202998.pdf 